\title{
First report of a linezolid-resistant MRSA (methicillin resistant Staphylococcus aureus) isolated from a dog with a severe bilateral otitis in Portugal
}

\author{
Seixas, R.; Monteiro, V.; Carneiro, C.; Vilela, C.L.; Oliveira, M. \\ CIISA/Faculdade de Medicina Veterinária da Universidade Técnica de Lisboa, Avenida da Universidade Técnica, \\ 1300-477 Lisboa, Portugal. Phone + 351 213852800; Fax + 351 213652889; E-mail: moliveira@fmv.utl.pt.
}

\begin{abstract}
Seixas, R.; Monteiro, V.; Carneiro, C.; Vilela, C.L.; Oliveira, M.: First report of a linezolid-resistant MRSA strain (methicillin resistant Staphylococcus aureus) isolated from a dog with a severe bilateral otitis in Portugal. Rev. vet. 22: 2, 81-84, 2011. The widespread use of antimicrobials has lead to the emergence of resistant bacteria to one or more antibiotic, including new drugs like linezolid. This antimicrobial is the first of the oxazolidinone group and soon after its approval in 2000, linezolid-resistant MRSA and linezolid vancomycinresistant enterococci have emerged. Several outbreaks of linezolid-resistant MRSA have been reported worldwide but, to our knowledge, this is the first report of a linezolid-resistant MRSA isolated from a dog in Portugal. The animal arrived at the Teaching Hospital of the Faculty of Veterinary Medicine, Technical University of Lisboa with a severe bilateral otitis that was refractory to antibiotic therapy. Bacteriology showed that the infection was caused by a multiresistant Staphylococcus aureus strain that also phenotipically expressed other virulence factors. Besides the challenge to practitioners, the isolation of this strain is of public health concern due to its antimicrobial resistant profile.
\end{abstract}

Key words: dog, linezolid, resistant Staphylococcus aureus (MRSA), Portugal.

\begin{abstract}
Resumen
Seixas, R.; Monteiro, V.; Carneiro, C.; Vilela, C.L.; Oliveira, M.: Resistencia a linezolida en una cepa de "Staphylococcus aureus resistente a la meticilina" (MRSA). Primer reporte de su aislamiento en un perro con severa otitis bilateral en Portugal. Rev. vet. 22: 2, 81-84, 2011. El uso extendido de antimicrobianos ha conducido a la aparición de bacterias resistentes a una o más clases de antibióticos, incluyendo nuevas drogas como la linezolida. Este antimicrobiano es el primero del grupo de oxazolidinonas; poco después de su aprobación en 2000 emergieron cepas de MRSA (Staphylococcus aureus resistente a la meticilina) resistentes a linezolida y enterococos resistentes a linezolida-vancomicina. Se han reportado varios brotes de MRSA linezolida-resistente a nivel mundial. Hasta donde conocemos, éste es el primer reporte de un MRSA linezolida-resistente aislado de un perro, en Portugal. El animal fue llevado al Hospital de la Facultad de Medicina Veterinaria de la Universidad Técnica de Lisboa con una severa otitis bilateral refractaria a la antibioticoterapia. La bacteriología reveló que la infección era causada por una cepa de $S$. aureus multirresistente, que también expresó fenotípicamente otros factores de virulencia. Además de un desafío para los clínicos, el aislamiento de esta cepa es preocupante para la salud pública debido a su perfil de resistencia antimicrobiana.
\end{abstract}

Palabras clave: perro, linezolida, Staphylococcus aureus resistente (MRSA), Portugal.

\section{INTRODUCTION}

The widespread use of antimicrobial compounds has contributed to the emergence of Staphylococcus aureus strains resistant to several antimicrobial groups, including new compounds ${ }^{21}$. Linezolid is the first antimicrobial of the oxazolidinone group, available since 2000. It interferes with protein synthesis by binding to the bacterial 50S ribosomal subunit. It's currently

Recibido: 12 septiembre 2011 / Aceptado: 4 octubre 2011 used for treatment of methicillin-susceptible and methicillin-resistant S. aureus (MSSA and MRSA, respectively) infections and vancomycin-resistant enterococci (VRE) ${ }^{1}$.

The linezolid surveillance network which monitored european medical centers for eight years (20022009) reported the emergence of linezolid-resistant bacteria in Ireland in 2007, France and Italy in 20062009, Germany in 2006, 2008 and 2009, Sweden in 2008 and United Kingdom in $2008{ }^{20}$. In the hospital environment, linezolid-resistant MRSA ${ }^{13}$ and linezol- 
id-resistant VRE ${ }^{11}$ emerged soon after its approval in 2000.

In addition to antimicrobial resistance traits, $S$. $a u$ reus may present a wide array of cell-surface and secretory virulence factors which may strongly influence infection outcome. They include surface adhesins that promote bacterial binding to the host ${ }^{8}$, biofilm that can protect the bacterial community from antimicrobials' action and host immune defences ${ }^{16}$, and lipases, proteases, hyaluronidases and nucleases which contribute to tissue destruction ${ }^{6}$.

Several clinical cases of linezolid-resistant MRSA have been reported worldwide ${ }^{10,13}$, but to our knowledge, this is the first description of a linezolid-resistant MRSA from animal origin in Portugal.

\section{MATERIALS AND METHODS}

A Rottweiler dog five year old with a history of recurrent otitis was carried to the Teaching Hospital of the Faculty of Veterinary Medicine, Technical University of Lisboa (FMV/UTL). Treatment with amoxicillinclavulanate $(22 \mathrm{mg} / \mathrm{kg}, \mathrm{SQ}, \mathrm{q} 24 \mathrm{~h})$ had been prescribed, for 15 days, without clinical success. The patient returned with a severe bilateral hypertrophic otitis with stenosis of the ear canal. Enrofloxacin $(10 \mathrm{mg} / \mathrm{kg}, \mathrm{SQ}$, q24h), and prednisolone (1 mg/kg, p.o., q12h) were then prescribed, for eight days, also without clinical success.

Ear swabs were taken from both ears for bacteriology and antimicrobial susceptibility testing. The dog was medicated the same day with topic chloramphenicol for 20 days. Given the laboratory results and poor clinical improvement, both ear canals were surgically removed.

Ear swabs were plated directed onto Columbia supplemented with 5\% sheep blood (BioMérieux), and MacConkey agar plates (Merck) incubated for 24 to 48 hours at $37^{\circ} \mathrm{C}$ under aerobic atmosphere. Enrichment cultures were performed (Brain heart infusion broth, BHIB, Difco), to allow the detection of more fastidious microorganisms. For strict anaerobes, samples were plated directed onto Schaedler agar plates (BioMérieux) and incubated for 48 hours at $37^{\circ} \mathrm{C}$ in the absence of oxygen, using an anaerobic jar (Anaerobic System, BioMérieux). Bacterial identification was performed using the API20E system (BioMérieux) and confirmed by PCR amplification as described by Pereira et al. ${ }^{18}$.

Antimicrobial susceptibility testing was performed by the disc diffusion method, according to the Clinical and Laboratory Standards Institute recommendations $^{3}$ : Aminoglycosides (amikacin $30 \mu \mathrm{g}$, gentamicin $10 \mu \mathrm{g}$, kanamycin $30 \mu \mathrm{g}$, neomycin $10 \mu \mathrm{g}$, streptomycin $10 \mu \mathrm{g}$, tobramycin $10 \mu \mathrm{g}$ ), carbapenems (imipenem 10 $\mu \mathrm{g}$ ), first generation cephalosporins (cephazolin $30 \mu \mathrm{g}$, cephalexin $30 \mu \mathrm{g}$ ), second generation cephalosporins (cefoxitin $30 \mu \mathrm{g}$ ), third generation cephalosporins (cefoperazone $75 \mu \mathrm{g}$, cephotaxime $30 \mu \mathrm{g}$ ), glycopeptides (vancomycin $30 \mu \mathrm{g}$ ), lincosamides (clindamycin $2 \mu \mathrm{g}$, lincomycin $2 \mu \mathrm{g}$ ), macrolides (erythromycin $15 \mu \mathrm{g}$ ), penicillins (cloxacillin $5 \mu \mathrm{g}$, oxacillin $1 \mu \mathrm{g}$, penicillin $\mathrm{G} 10 \mathrm{U}$ ) and penicillin combinations (amoxicillin-clavulanate $30 \mu \mathrm{g}$ ), fluoroquinolones (ciprofloxacin $5 \mu \mathrm{g}$, enrofloxacin $5 \mu \mathrm{g}$, nalidixic acid $30 \mu \mathrm{g}$, norfloxacin 10 $\mu \mathrm{g}$ ), oxazolidinones (linezolid $30 \mu \mathrm{g}$ ), phenicols (chloramphenicol $30 \mu \mathrm{g}$ ), sulphonamides (sulphamethoxazole-trimethoprim, $25 \mu \mathrm{g}$ ), tetracyclines (tetracycline $30 \mu \mathrm{g})$, and fusidic acid $(10 \mu \mathrm{g})$ were used. All discs were purchased from Oxoid. PCR amplification was performed to confirm the presence of mecA gene ${ }^{18}$. Virulence phenotypic characterization was also performed, as follows:

-Haemolytic activity-isolate was plated onto Columbia agar supplemented with 5\% sheep blood (BioMérieux) and incubated at $37^{\circ} \mathrm{C}$ for $48 \mathrm{~h}$ under aerobic conditions. The presence of a transparent halo surrounding the colonies was registered as $\beta$-hemolysis ${ }^{19}$.

-Gelatinase activity-isolate was plated onto gelatinase test agar (Liofilchem). After incubation for $48 \mathrm{~h}$ at $37^{\circ} \mathrm{C}$, the plate was flooded with a saturated solution of ammonium sulphate. A positive result was revealed by the presence of a transparent halo around bacterial colonies $^{22}$.

-Deoxyribonuclease activity-isolate was plated onto DNase test agar (Liofilchem). After an incubation of 48 $\mathrm{h}$ at $37^{\circ} \mathrm{C}$, the plate was flooded with hydrochloric acid (1N). Positive DNase activity was revealed by the presence of clear zone around bacterial colonies ${ }^{25}$.

-Biofilm production-isolate was plated onto Congo red agar (Sigma-Aldrich) and the plate was incubated for $24 \mathrm{~h}$ at $37^{\circ} \mathrm{C}$. Biofilm producer isolates originate black colonies, while non-producers remain red ${ }^{9}$.

-Coagulase activity-isolate was inoculated in BHIB and incubated at $37^{\circ} \mathrm{C}$ for $24 \mathrm{~h}$. A volume of $100 \mu \mathrm{l}$ of the broth culture was added to $300 \mu 1$ of EDTA rabbit plasma (VWR) and incubated at $37^{\circ} \mathrm{C}$ for $24 \mathrm{~h}$. Coagulase activity was revealed by gel formation ${ }^{23}$.

\section{RESULTS AND DISCUSSION}

This report describes a case of a severe bilateral otitis in a dog caused by linezolid-resistant MRSA. The dog had a history of otitis for two months and had been subjected to three therapeutic protocols before bacteriological and antimicrobial susceptibility tests here done. Laboratory results showed that the infection was caused by $S$. aureus, isolated in pure culture. Staphylococci are the most common bacteria responsible of canine otitis. Antimicrobial resistance of staphylococci isolated from dog's ear is frequent and a high percentage of the isolates are multiresistant ${ }^{14,17}$.

In our study, a wide range of antimicrobials was tested, and the isolate only revealed susceptibility to chloramphenicol, fusidic acid, linezolid and vancomycin. The emergence of multiresistant strains require different therapeutic strategies to overcome selective pressure while improving clinical success. Some of the "old" antimicrobials have not been widely use in recent years, being active against a large number of prevalent 
bacterial isolates ${ }^{7,15}$. Chloramphenicol and fusidic acid are examples of re-emerging compounds for treatment of multidrug resistance bacteria, being inexpensive alternatives for the treatment of MRSA infections ${ }^{7,15}$.

The strategy of using new or last-generation compounds should be carefully taken into consideration, weighing the risk of inducing antimicrobial resistance versus the need for medical care. Linezolid and vancomycin are newer compounds used as "last resource" for the treatment of MRSA infections in humans. Although the majority of the staphylococcal isolates from animal source remain susceptible to these drugs ${ }^{2}$, they are not licensed for veterinary use and could cause adverse reactions or have poor pharmacokinetic in small animals ${ }^{5}$ which leave veterinary clinicians with little therapeutical options. Resistance to linezolid among MRSA is reported to be very rare ${ }^{21}$, but the isolate studied showed to be resistant to this drug.

$S$. aureus possesses a wide array of virulence factors, including extracellular toxins and surface structures that facilitate immune evasion, tissue colonization and destruction ${ }^{24}$. The isolate under study was $\beta$-haemolytic, coagulase-positive and DNAse and gelatinase producer. The production of exo-enzymes has been reported among $S$. aureus from different sources ${ }^{4,12}$ and has been related to bacterial virulence. This isolate did not express biofilm, another recognized virulence factor in staphylococci, which is in agreement with previous studies that showed that biofilm production is more prevalent in MSSA than in MRSA ${ }^{24}$.

Taken together, the results suggest that this isolate has an increased ability to colonize and cause tissular disruption and is resistant to all available antimicrobials licensed for veterinary medicine. Linezolid-resistance outbreaks in human medical centers are becoming more frequently reported worldwide ${ }^{10}$, rising concerns about human and animal health safety. To our knowledge, this is the first report of a linezolid-resistant MRSA isolated from an animal source. Multidrug linezolid-resistant MRSA from animal origin are challenge to practitioners and the spread of this strain may be of worldwide concern.

Acknowledgments. This work was supported by Interdisciplinary Centre of Research in Animal Health. M. Oliveira is a researcher from the program "Ciência 2007" from Foundation for Science and Technology (FCT), Portugal.

\section{REFERENCES}

1. Arias VM, Reyes J, Panesso D, Moreno J, Castañeda M, Villegas M, Murray B, Quinn J. 2008. Clinical and microbiological aspects of linezolid resistance mediated by the cfr gene encoding a $23 \mathrm{~S}$ rRNA methyltransferase. $J$ Clin Microbiol 46: 892-896.

2. Baba K, Ishihara K, Ozawa M, Tamura Y, Asai T. 2010. Isolation of methicillin-resistant Staphylococcus aureus
(MRSA) from swine in Japan. J Antimicr Agents 36: 352354.

3. Clinical and Laboratory Standards Institute (CLSI). 2007. Performance standards for antimicrobial susceptibility testing. Seventeenth Informational Supplement in Document M100-S17, 27: 1.

4. Coelho S, Reinoso E, Pereira I, Soares L, Demo M, Bogni C, Souza M. 2009. Virulence factors and antimicrobial resistance of Staphylococcus aureus isolated from bovine mastitis in Rio de Janeiro. Pesq Vet Bras 29: 369374.

5. Couto N, Pomba C, Moodley A, Guardabassi L. 2011. Prevalence of methicillin-resistant staphylococci among dogs and cats at a veterinary teaching hospital in Portugal. Vet Rec 162: 72 .

6. Dinges MM, Orwin PM, Schlievert PM. 2000. Exotoxins of Staphylococcus aureus. Clin Microbiol Rev 13: 1634.

7. Falagas ME, Grammatikos AP, Michalopoulos A. 2008. Potential of old-generation antibiotics to address current need for new antibiotics. Expert Rev Anti Infect Ther 6: 593-600.

8. Foster TJ, Hook M. 1998. Surface protein adhesins of Staphylococcus aureus. Trends Microbiol 6: 484-488.

9. Freeman D, Falkiner F, Keane C. 1989. New method for detecting slime production by coagulase negative staphylococci. J Clin Pathol 42: 872-874.

10. García M. 2010. Clinical outbreak of linezolid-resistant Staphylococcus aureus in an intensive care unit. JAMA 303: 2260-2264.

11. Gonzales RD, Schreckenberger PC, Graham MB, Kelkar S, Denbesten K, Quinn JP. 2001. Infections due to vancomycin-resistant Enterococcus faecium resistant to linezolid. Lancet 357: 1179.

12. Gündoğan N, Citak S, Turan E. 2006. Slime production, DNase activity and antibiotic resistance of Staphylococcus aureus isolated from raw milk, pasteurised milk and ice cream samples. Food Contr 17: 389-392.

13. Ikeda-Dantsuji Y. 2010. Linezolid-resistant Staphylococcus aureus isolated from 2006 through 2008 at six hospitals in Japan. J Infect Chemother 17: 45-51.

14. Lilenbaum W, Veras M, Blum E, Souza GN. 2000. Antimicrobial susceptibility of staphylococci isolated from otitis externa in dogs. Appl Microbiol 31: 42-45.

15. Maviglia R, Nestorini R, Pennisi M. 2009. Role of old antibiotics in multidrug resistant bacterial infections. Curr Drug Targ 9: 895-905.

16. O'Riordan K, Lee JC. 2004. Staphylococcus aureus capsular polysaccharides. Clin Microbiol Rev 17: 218-234.

17. Penna P, Varges R, Medeiros L, Martins G, Martins R, Lilenbaum W. 2010. Species distribution and antimicrobial susceptibility of staphylococci isolate from canine otitis externa. Vet Dermatol 21: 292-296.

18. Pereira EM, Malvar KL, Iorio NL, Matos PD, Olendzki AN, Oelemann WM, dos Santos KR. 2010. Staphylococcus aureus, Staphylococcus epidermidis and Staphylococcus haemolyticus: methicillin-resistant isolates are detected directly in blood cultures by multiplex PCR. Microbiol Res 165: 243-249. 
19. Pereira V, Lopes C, Castro A, Silva J, Gibbs P, Teixeira P. 2009. Characterization for enterotoxin production, virulence factors, and antibiotic susceptibility of Staphylococcus aureus isolates from various foods in Portugal. Food Microbiol 26: 278-282.

20. Ross JE, Farrell DJ, Mendes RE, Sader HS, Jones RN. 2011. Eight-year (2002-2009) summary of the linezolid program in European countries. $J$ Chemother 23: 71-76.

21. Sakoulas G, Moellering R. 2008. Increasing antibiotic resistance among methicillin resistant Staphylococcus aureus strains. Clin Infect Dis 46: 360-367.

22. Semedo T, Santos MA, Lopes MF, Figueiredo JJ, Barreto MT, Tenreiro R. 2003. Virulence factors in food, clinical and reference enterococci: a common trait in the genus? System Appl Microbiol 26: 13-22.
23. Sperber W, Tatini S. 1975. Interpretation of the tube coagulase test for identification of Staphylococcus aureus. Appl Microbiol 29: 502-505.

24. Wang L, Yu F, Yang L, Li Q, Zhang X, Zeng Y, Xu Y. 2010. Prevalence of virulence genes and biofilm formation among Staphylococcus aureus clinical isolates associated with lower respiratory infection. Afr J Microbiol Res 4: 2566-2569.

25. Weckman BG, Catlin BW. 1957. Deoxyribonuclease activity of micrococci from clinical sources. J Bacteriol 73: 747-753. 